\title{
Linking Plant Spatial Patterns and Ecological Processes in Grazed Great Basin Plant Communities
}

\author{
Andrew P. Rayburn ${ }^{1}$ and Thomas A. Monaco ${ }^{2}$ \\ Authors are ${ }^{1}$ PhD Candidate, Department of Wildland Resources and the Ecology Center, 5305 Old Main Hill, Utah State University, Logan, UT 84322- \\ 5305, USA; and ${ }^{2}$ Research Ecologist, Forage and Range Research Lab, 690 North 1100 East, Utah State University, Logan, UT 84322-6300, USA.
}

\begin{abstract}
Observational studies of plant spatial patterns are common, but are often criticized for lacking a temporal component and for their inability to disentangle the effect of multiple community-structuring processes on plant spatial patterns. We addressed these criticisms in an observational study of Great Basin shrub-steppe communities that have been converted to a managed grazing system of planted crested wheatgrass (Agropyron cristatum [L.] Gaertn.) stands. We hypothesized that intraspecific interference and livestock grazing were important community-structuring processes that would leave unique spatiotemporal signatures. We used a survey-grade global positioning system to quantify crested wheatgrass spatial patterns along a chronosequence of stands that differed only in time since planting $(9-57 \mathrm{yr})$, as well as in a 57-yr-old grazing exclosure to examine pattern formation in the absence of grazing. Three replicate survey plots were established in each stand, and a total of 6197 grasses were marked with a spatial error of $\leq 2 \mathrm{~cm}$. The data were analyzed using L-statistics in program R, and hypothesis testing was conducted using Monte Carlo simulation procedures. We detected fine-scale regularity, frequently considered a sign of interference via resource competition, in all stands including the exclosure. Coarser-scale aggregation, which we attributed to the effects of prolonged grazing disturbance, was only detected in the oldest grazed stand. Our results suggest that interference acts over finer spatial and temporal scales than grazing in structuring these stands, reinforcing the importance of interference in semiarid communities. Analysis of exclosure data suggests that, in the absence of grazing, crested wheatgrass stands organize into a statistically regular pattern when primarily influenced by interference. In the presence of prolonged grazing, crested wheatgrass stands become more heterogeneous over time, likely a result of seedling mortality via disturbance by cattle.
\end{abstract}

\section{Resumen}

Los estudios observacionales de los patrones espaciales de la vegetación son comunes, pero frecuentemente son criticados por carecer de un componente temporal y por su inhabilidad para desentrañar el efecto de los múltiples procesos que dan estructura a los patrones espaciales de la vegetación. Se abordaron estas críticas en un estudio observacional de comunidades de estepa arbustiva del Great Basin (EE.UU.) que han sido convertidas a sistemas pastoriles manejados con la implantación de agropiro crestado (Agropyron cristatum (L.) Gaertn.). Se postuló la hipótesis de que la interferencia intra-específica y el pastoreo del ganado son procesos importantes que generan estructura en la vegetación y que dejan una marca espaciotemporal singular. Use utilizó un GPS de alta precisión para cuantificar los patrones espaciales de agropiro crestado a lo largo de una cronosecuencia de poblaciones que diferían sólo en el tiempo desde el cultivo (9-57 años), así como en una clausura al pastoreo de 57 años para examinar la formación de patrones en ausencia de pastoreo. Tres parcelas de relevamiento replicadas fueron establecidas en cada población, y un total de 6.197 pastos fueron marcados con un error espacial de $\leq 2 \mathrm{~cm}$. Los datos fueron analizados utilizando el test L en el paquete R, y las hipótesis fueron puestas a prueba usando procedimientos de simulación de Monte Carlo. Se detectó regularidad a escala fina, frecuentemente considerada como una señal de interferencia por medio de competencia por los recursos, en todas las poblaciones incluyendo la clausura. A escalas más gruesas, las que fueron atribuidas a los efectos de disturbio prolongado del pastoreo, sólo se detectó agregación en la población con más años de pastoreo. Nuestros resultados sugieren que la interferencia genera estructura a escalas espaciotemporales más finas que el pastoreo, lo que refuerza la importancia de la interferencia en comunidades semiáridas. El análisis de los datos de la clausura sugiere que, en ausencia de pastoreo, las poblaciones de agropiro crestado se organizan siguiendo un patrón estadísticamente regular cuando están influenciadas principalmente por interferencia. En la presencia de pastoreo prolongado, las poblaciones de agropiro crestado se vuelven más heterogéneas a través del tiempo, probablemente como consecuencia de la mortalidad de plántulas promovida por el disturbio del pastoreo.

Key Words: Agropyron cristatum, disturbance, interference, managed grazing system, spatial pattern analysis

This study was financially supported by an S. J. and Jesse E. Quinney Doctoral Fellowship to A.P.R., the Utah State University Ecology Center, the Utah Agricultural Experiment Station at Utah State University, and the Sagebrush Steppe Treatment Evaluation Project, which is funded by the US Joint Fire Science Program.

Correspondence: Andrew P. Rayburn, Dept of Wildland Resources, College of Natural Resources, NR 206, Utah State University, 5230 Old Main Hill, Logan, UT 84322-5430, USA. Email: drew.rayburn@usu.edu

Manuscript received 5 August 2010; manuscript accepted 12 February 2011.

\section{INTRODUCTION}

Research on plant spatial patterns is often conducted to better understand the interplay between patterns and ecological processes affecting individual plants and plant communities (Stoll and Prati 2001; Armas and Pugnaire 2005; Mokeny et al. 2008; Law et al. 2009). Such processes include competitive or facilitative interactions between individual plants (Kenkel 
1988; Stoll and Prati 2001; Murrell 2009); the effect of environmental heterogeneity on plant survival, growth, and distribution (Maestre et al. 2003; Schenk et al. 2003; Tirado and Pugnaire 2003); and disturbance (Adler et al. 2001; Bisigato et al. 2005). For example, statistically regular plant spatial patterns are often assumed to result from intense local competition for limited resources (e.g., Kenkel 1988).

Observational studies involving snapshot sampling (a single set of observations without a temporal component) of plant spatial patterns have been frequently conducted (e.g., Phillips and MacMahon 1981; Skarpe 1991; Schenk et al. 2003). However, attempts to link the observed patterns to communitystructuring ecological processes have been criticized on the grounds that such studies lack a temporal component and that dynamic ecological processes operate over space and time simultaneously (Lepš 1990; Law et al. 2009). A related criticism is that multiple interacting processes may generate similar plant patterns, and that observational studies of plant pattern formation may be unable to disentangle the effects of multiple processes without additional experimental studies that may be difficult or impossible in the field (McIntire and Fajardo 2009). Recent observational studies of pattern and process have overcome these hurdles by using combinations of a priori hypotheses, ecologically informed expectations, and precise spatial analyses that elucidate both the nature of emergent patterns and the scale over which the patterns are detected (e.g., Wiegand et al. 2007; McIntire and Fajardo 2009). However, without a temporal component, there is substantial uncertainty as to the relationship between pattern and process over time (Law et al. 2009).

One potential way to include a temporal dimension in snapshot studies is to study sites that are as similar as possible in environmental and edaphic characteristics, but that vary along a temporal gradient, or chronosequence. If all sites are exposed to the same suite of pattern-forming processes, and if patterns have unique spatial signatures, then a study of sites along the chronosequence may reveal how the processes influence the pattern through time. In this manner, it would be possible to conduct observational studies of plant patterns that nearly equal the power of controlled experiments and which more directly link the observed patterns to communitystructuring processes. In this study, we sought to demonstrate this approach across a chronosequence of grazed crested wheatgrass (Agropyron cristatum [L.] Gaertn.) stands in southeastern Idaho to examine pattern formation and stand dynamics through time in response to two ecological processes: intraspecific interference via resource competition and grazing disturbance.

First introduced into the United States from its native range in Russia in 1898 by N. E. Hansen as a promising pasture grass, crested wheatgrass began to be planted in the Great Basin region of the western United States in the 1930s (Hull and Klomp 1966; Rogler and Lorenz 1983). Crested wheatgrass has many desirable characteristics, such as being a strong competitor against troublesome invasive species such as downy brome (Bromus tectorum L.; Aguirre and Johnson 1991; Chatterton and Harrison 2003), high grazing tolerance (Sharp 1986; Angell 1997), drought tolerance (Caldwell and Richards 1986; Sharp et al. 1992), long life (Hull and Klomp 1966), and a high rate of seed production (Marlette and Anderson 1986). To date, millions of hectares of big sagebrush (Artemisia tridentata Nutt.)-steppe ecosystems have been seeded with crested wheatgrass in the Great Basin to rehabilitate damaged wildlands and to provide forage within managed grazing systems (Rogler and Lorenz 1983; Pellant and Lysne 2005). Although there is substantial variability across present-day Great Basin crested wheatgrass stands related to soils, time since planting, planting method, land use history, and disturbance history, there are subsets of stands that are very similar in most respects except that they differ in age since planting.

Crested wheatgrass was historically planted in monoculture (Fig. 1), although more recently it has been included in seed mixtures with native grasses and forbs to facilitate more diverse communities (Pellant and Lysne 2005). Although seedling mortality often occurred as a result of poor seedling emergence and survival, grazing (Balph and Malechek 1985; Salihi and Norton 1987), or competition with existing plants (Hull and Klomp 1967), newly established stands of crested wheatgrass had a distinctly regular pattern similar to agricultural fields.

In years following establishment, these stands were subject to a variety of community structuring processes that may have influenced the spatial pattern of grasses, such as dispersal and seedling establishment, interference via resource competition, and grazing disturbance. For example, Balph and Malechek (1985) reported that cattle avoided walking on the tussocks of established crested wheatgrass plants, preferring instead to move through tussock interspaces. Salihi and Norton (1987) reported extremely high seedling mortality in the same study area, which they attributed to the effects of trampling as cattle moved through interspaces between tussocks, where over $90 \%$ of seedlings emerged. In addition to trampling, high levels of grazing may lead to reduced vigor and even mortality of mature crested wheatgrass plants (Pellant and Lysne 2005).

Crested wheatgrass spatial patterns are also likely influenced by intraspecific interference (rather than interspecific interference, as many of the stands have persisted as near-monocultures for decades after establishment; Hull and Klomp 1966; Marlette and Anderson 1986; Kindschy 1991). Interference via resource competition between individual grasses for water and nutrients has been reported for established crested wheatgrass stands and in controlled experiments (Keller and Bleak 1984; Salihi and Norton 1987; Olsen and Richards 1989; Asay and Johnson 1997). For example, Salihi and Norton (1987) found that crested wheatgrass seedlings in both grazed and ungrazed stands most often emerged in bare soil $>10 \mathrm{~cm}$ from established grasses. The same study found that emergent seedlings that were farther away from established grasses also had the highest rate of survival. Intense intraspecific interference is most likely contributing strongly to the regularly spaced plant patterns that are a hallmark of certain mature crested wheatgrass stands in the Great Basin (Fig. 1A).

In this study, we sought to quantify long-term changes in grass spatial patterns to better understand how these processes have acted over space and time to structure crested wheatgrass stands in the Great Basin. Evaluating the relationship between plant spatial patterns and community-structuring processes within these stands is timely as managed grazing systems worldwide are challenged with changing bioclimatic, edaphic, and socioeconomic pressures (Asner et al. 2004). Our expectations took the form of a priori hypotheses as advocated 

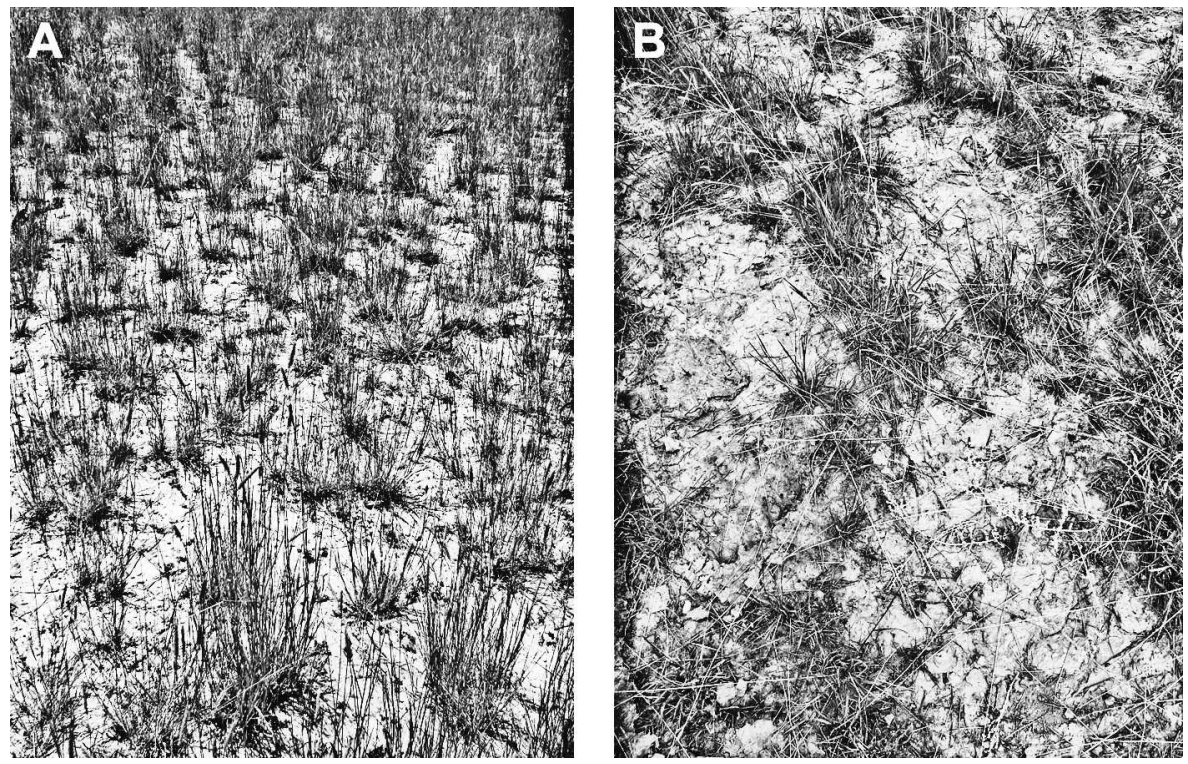

Figure 1. Photographs taken in 2010 of $57-y r-o l d ~ c r e s t e d$ wheatgrass stand in Oneida County, Idaho. A, Visually regular pattern associated with mature, ungrazed stand, and $\mathbf{B}$, example of aggregation in grass distribution within an adjacent grazed stand. Photographs by A. Rayburn.

in recent publications regarding appropriate inferences made from observational studies of plant spatial patterns (e.g., McIntire and Fajardo 2009).

Our general hypothesis was that interference and disturbance were important ecological processes determining grass spatial patterns, but that each would leave unique spatiotemporal signatures and act at different spatial scales owing to the specific nature of each process. This hypothesis was based on the assumption that intense intraspecific interference between grasses would likely lead to regularity between crested wheatgrass plants at a scale that reflects the zone of interactions between individual plants, as has been observed in other plant communities structured by competition (e.g., Kenkel 1988). Based on relatively scarce information in the literature, and on our own observations of interplant distances within a grazing exclosure (mean nearest neighbor distance $\pm 1 \mathrm{SE}$ measured between centroids $=0.17 \pm 0.004 \mathrm{~m}, N=285$ grasses), we specifically predicted that fine-scale regularity would be detected at a scale of $<0.2 \mathrm{~m}$. Conversely, we predicted that disturbance via cattle would be expected to lead to aggregation at a scale that reflected the movement and grazing patterns of cattle across the stand. As noted above, previous studies have reported that cattle tended to avoid tussocks of mature crested wheatgrass and walk instead in the interspaces between grasses. Based on field observations of grass interspaces and cattle movement throughout the study plots, we specifically predicted that aggregation would be detected at a larger scale than regularity $(>0.2 \mathrm{~m})$. Relative to the temporal dimension, we predicted that spatial signatures of both processes would be detected in older stands, but that aggregation would not be detected in younger stands owing to a lack of stand development and lack of prolonged grazing disturbance.

\section{METHODS}

The study stands of crested wheatgrass were located in Oneida County, southeastern Idaho. Two grazed stands (Bowhuis and
South Black Pine) were located within $3.2 \mathrm{~km}$ of one another on public land administered by the Bureau of Land Management (US Department of the Interior), as was the grazing exclosure we included in the study to control for the effects of grazing on pattern formation. The third grazed stand (North Carter) was located $\sim 23 \mathrm{~km}$ away within Curlew National Grasslands, which is administered by the Forest Service (US Department of Agriculture).

Prior to plot establishment, the age of each stand was determined either from previous published work (Williams 2009) or from interviews with local management agency staff. Stands varied in time since planting from $9 \mathrm{yr}$ to $57 \mathrm{yr}$, but were similar in terms of site preparation prior to planting, planting method, disturbance history, and ecological site descriptions (ESDs; USDA NRCS 2010; Table 1). In addition, ESDs indicated that all four stands historically supported Wyoming big sagebrush-bluebunch wheatgrass (Pseudoroegneria spicata [Pursh] A. Löve) plant communities. Replicate stands were not available in the region, because many stands had previously burned and/or had been established and managed using different methods. The exact grazing history for each stand was difficult to determine; however, all grazed stands in the study have experienced high stocking rates and intensive grazing annually since their establishment (Williams 2009). The stand in which the exclosure was located was planted at the same time as the South Black Pine stand, whereas the grazing exclosure itself was constructed approximately $40 \mathrm{yr}$ ago. The inclusion of additional, younger exclosures in the study would have been preferable; however, no other exclosures existed in the region. Although domestic cattle and sheep were not permitted into the exclosure, wildlife could freely enter by leaping the fence or passing through gaps in the fence. None of the study stands have experienced fire since they were seeded with crested wheatgrass. Stands were characterized by flat topography, uniformity in vegetation height, and little to no woody vegetation.

Three $5 \times 5 \mathrm{~m}$ plots were established in each grazed stand, as well as in the exclosure. Within each plot, all perennial 
Table 1. Characteristics of the four crested wheatgrass study stands measured in $25-\mathrm{m}^{2}$ plots. All stands had identical preseeding treatments (plowing), seeding methods (drill), and postseeding treatments (none). Three sites (Bowhuis, South Black Pine, exclosure) share identical ecological site descriptions (ESD; ESD code R028AY024ID), whereas the ESD for the remaining site (North Carter) has potentially greater annual precipitation and coarser soils (ESD code R028AY025ID).

\begin{tabular}{|c|c|c|c|c|c|c|}
\hline Stand & Plot & Density (plants $\cdot \mathrm{m}^{-2}$ ) & Stand age (yr) & Mean annual precipitation (mm) & Soil texture & Disturbance history \\
\hline \multirow[t]{4}{*}{ North Carter } & & & 9 & $280-330$ & Gravelly silt loam & Grazed yearly \\
\hline & 1 & 16.4 & & & & \\
\hline & 2 & 18.1 & & & & \\
\hline & 3 & 7.1 & & & & \\
\hline \multirow[t]{4}{*}{ Bowhuis } & & & 37 & $203-355$ & Silt loam & Grazed yearly \\
\hline & 1 & 33.4 & & & & \\
\hline & 2 & 29.2 & & & & \\
\hline & 3 & 34.3 & & & & \\
\hline \multirow[t]{4}{*}{ South Black Pine } & & & 57 & $203-355$ & Silt loam & Grazed yearly \\
\hline & 1 & 25.8 & & & & \\
\hline & 2 & 16.4 & & & & \\
\hline & 3 & 30.0 & & & & \\
\hline \multirow[t]{4}{*}{ Exclosure } & & & 57 & $203-355$ & Silt loam & Ungrazed \\
\hline & 1 & 11.4 & & & & \\
\hline & 2 & 14.6 & & & & \\
\hline & 3 & 11.2 & & & & \\
\hline
\end{tabular}

vegetation was identified and mapped using the ProMark3 global positioning system (GPS), a survey-grade GPS unit that enables both rapid and precise data collection (Rayburn et al. 2010). GPS data were collected at the approximate centroids of each plant. Plots were essentially monocultures, with no other perennial or woody species present and only scattered annual vegetation.

Field GPS data was post-processed using GNSS Solutions software (v. 3.10.01, Magellan Navigation, Santa Clara, CA), and the resulting $x, y$ coordinates of plants had an estimated spatial error of $\leq 2 \mathrm{~cm}$. Coordinates were exported as delimited text files for statistical analysis in $\mathrm{R}$ ( $\mathrm{R}$ Development Core Team 2011) using both base functions and the spatstat package for spatial analysis of point patterns (Baddeley and Turner 2005). We implemented the common second-order spatial statistic Ripley's K (Ripley 1981), which evaluates the number of points within a certain distance $(r)$ of a randomly chosen point relative to expectations based on the density of points in the study area The approximately unbiased estimator for $K(r)$ is

$$
\hat{K}(r)=n^{-2} A \sum \sum w_{i j}{ }^{-1} I_{r}\left(u_{i j}\right)
$$

where $n$ is the number of plants in the study plot, $A$ is plot area, $I_{r}$ is a counter variable, $u_{i j}$ is the distance between events $i$ and $j$, and $w_{i j}$ is a weighting factor to correct for edge effects (Haase 1995). A variety of null models and edge corrections may be implemented for $K$-statistics, depending on the nature of the analysis. Significant deviations of the $K$-statistic indicate either regularity or aggregation at scale $r$ in a spatial point pattern dataset, assuming an appropriate null model has been fit. $K$ statistics are often square-root transformed $(L(r)=\sqrt{[K(r) / \pi]}$, following Besag 1977) to stabilize variance, and plotted using $(L(r)-r)$ against $r$ since this derived function has an expectation of 0 for all values of $r$ under the null hypothesis of complete spatial randomness (CSR; Skarpe 1991).
We evaluated the crested wheatgrass spatial data using a CSR null model coupled with reduced sample edge correction and Monte Carlo permutation procedures $\left(N_{\text {sim }}=199\right)$ to allow for hypothesis testing. The CSR null model was appropriate as there were no obvious first-order effects influencing patterns of crested wheatgrass.

\section{RESULTS}

A total of 6197 grasses were mapped across the 12 study plots. Grass densities varied from 7.1 grasses $\cdot \mathrm{m}^{-2}$ to 34.3 grasses $\cdot \mathrm{m}^{-2}$, and densities were generally higher in the older grazed plots than in the young grazed plots and the exclosure plots (Table 1). Significant fine-scale $(r<0.2 \mathrm{~m})$ regularity was detected in all nine grazed study plots (Figs. 2A-2I), with broader-scale $(r>0.6 \mathrm{~m})$ regularity detected in one of the 9-yrold study plots (Fig. 2E). Significant fine-scale regularity was also detected in all three exclosure plots (Figs. 2J-2L), albeit across a broader scale in two of the three plots $(r \approx 0.0-0.8 \mathrm{~m}$ and $r \approx 0.0-0.6 \mathrm{~m}$; Figs. 2J and 2L). Significant aggregation was only detected in the older grazed plots. In two plots within the oldest stand, significant aggregation was detected at broader scales than regularity $(r \approx 0.1-0.4 \mathrm{~m}$ and $r \approx 0.1-$ $0.8 \mathrm{~m}$; Figs. $2 \mathrm{H}$ and $2 \mathrm{I})$. There was also suggestive evidence of significant aggregation in two plots within the intermediateaged stand $(r \approx 0.2 \mathrm{~m}$ and $r \approx 0.2 \mathrm{~m}$; Figs. $2 \mathrm{E}$ and $2 \mathrm{~F})$. By suggestive, we mean that the values of the L-statistic were extremely close to the values of the null model, and that results should be interpreted with caution (Blanco et al. 2008).

\section{DISCUSSION}

Observational studies of plant spatial patterns are common, but have been criticized on the grounds that they lack the power of 

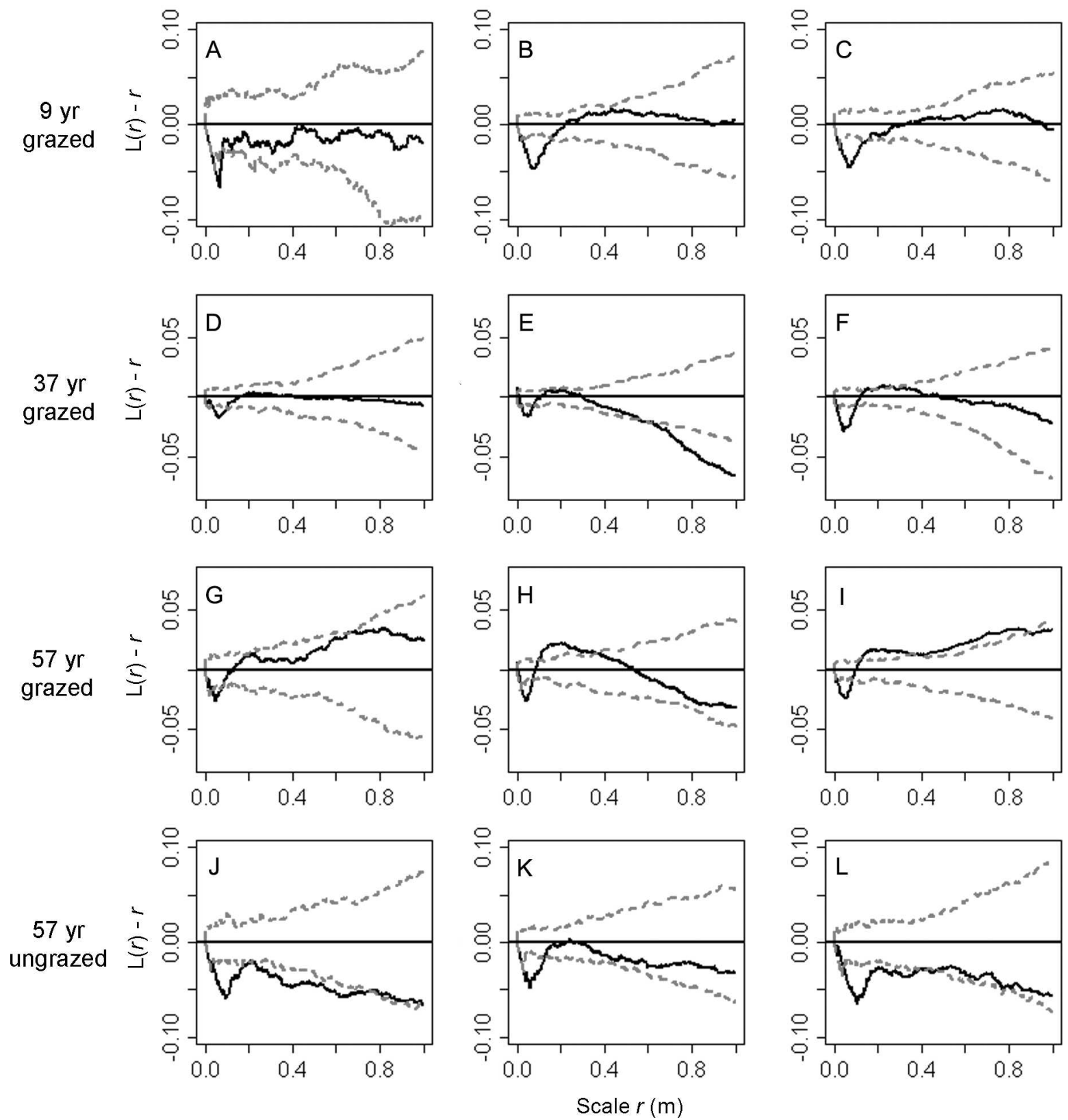

Figure 2. L-function plots for A-C, North Carter (9 yr grazed); D-F, Bowhuis (37 yr grazed); G-I, South Black Pine (57 yr grazed); and J-L, exclosure (57 yr grazed). Solid lines represent the estimated L-statistics plotted as $L(r)-r$. Dotted lines represent Monte Carlo simulation envelopes $\left(N_{\text {sim }}=199\right)$. Values of $L(r)-r$ greater than the upper simulation envelope indicate significant aggregation relative to the null hypothesis of complete spatial randomness (e.g., plot $\mathbf{H}$ ), whereas values less than the lower simulation envelope indicate significant regularity (e.g., plot A). Horizontal axis values represent the scale ( $r$, in meters) over which the pattern was tested. Plots are not displayed at $r>1.0 \mathrm{~m}$ because plants are assumed to interact only at fine scales $(r<1.0 \mathrm{~m})$.

experimental studies for connecting pattern and process in plant communities. Ideally, one would conduct a complete spatiotemporal experiment in which the type and magnitude of ecological processes were known and in which established plots or study regions were monitored over a sufficiently long period of time to track population data in addition to changes in plant spatial patterns. Examples of these kinds of studies are rare, however, owing in no small part to the difficulties in establishing such experiments, and have tended to focus on the effects of aggregation on species coexistence (Stoll and Prati 2001; Monzeglio and Stoll 2005; Mokeny et al. 2008).

In this study, we sought to partially address past criticisms of observational studies by using an approach designed to disentangle the long-term effects of grazing disturbance and intraspecific interference via resource competition on plant patterns in grazed Great Basin crested wheatgrass stands. We hypothesized that competition would rapidly lead to fine-scale regularity between individual grasses, whereas grazing would 
likely lead to aggregation at coarser spatiotemporal scales. Our GPS-based approach allowed us to precisely quantify grass spatial patterns, allowing us to test for unique spatial signatures of grazing and competition using second-order spatial statistics. By collecting spatial data on grass patterns across a chronosequence of similar stands, we enhanced our understanding of the temporal scales at which the processes under study act to structure the community. We suggest that this methodology could be useful in other community types where multiple ecological processes are under study and long-term field experiments are not tractable.

Our results strongly suggest that crested wheatgrass stands are simultaneously structured by both interference and grazing, albeit at different spatiotemporal scales. At fine spatial scales, we detected significant regularity between individual plants in all plots, which we attribute to strong local competitive interactions for water and nutrients. This regularity is likely not simply a relict of the initial pattern of planting; substantial rearrangement (relative to linear rows) of crested wheatgrass plants was apparent in even the youngest plots. Previous studies have found that crested wheatgrass stands could quickly thicken and spread relative to the initial pattern of planting (Weintraub 1953; Hull and Klomp 1966, 1967), likely due to high levels of seed production in crested wheatgrass (Marlette and Anderson 1986) coupled with interspaces between planted rows that provided room for seedling establishment. As space for new recruits became more limited, it is likely that intraspecific competition for resources quickly became an important community structuring process. Competition is likely more intense in the exclosure, as evidenced by the detection of regularity across broader scales in exclosure plots as compared to grazed plots.

At coarser spatial scales, we detected significant aggregation in two of the three oldest crested wheatgrass plots examined, which we attribute to the effects of sustained disturbance by cattle. Generally, it is well known that grazing disturbance has profound effects on the spatial pattern of vegetation (Adler et al. 2001; Adler and Hall 2005; Henkin et al. 2007). Depending on the characteristics of species being grazed, grazing intensity, and on the other biotic and abiotic characteristics of the community, grazing is known to influence the spatial structure of the grazed species (Seifan and Kadmon 2006), plant interactions within the community (Murrell et al. 2001), biomass production (Seifan and Kadmon 2006), and plant mortality (Salihi and Norton 1987; Huntly 1991).

In our study, the observed aggregation in the oldest stand was likely the result of decades of cattle moving through interspaces between established crested wheatgrass tussocks, leading to increased seedling mortality in the interspaces as observed in past studies of grazed crested wheatgrass stands (Balph and Malechek 1985; Salihi and Norton 1987). This effect is exacerbated in older stands, as crested wheatgrass tussocks become more elevated relative to the surrounding substrate (Balph and Malechek 1985). In young stands without significant tussock development, cattle are likely to step more randomly throughout the stand; as tussocks form, cattle are more likely to step in the interspaces to avoid the uneven terrain associated with the tussocks. These interspaces undergo additional soil compaction, resulting in a positive feedback mechanism as soil compaction increases the elevation of surrounding tussocks, which in turn increases nonrandom movement of cattle through the stand (Balph and
Malechek 1985) and subsequent aggregation. The creation of cattle trails in crested wheatgrass stands represents the extreme case of the above scenario, as soil is very compacted on trails and few if any seedlings are present. In the absence of trails, however, significant patchiness may form in crested wheatgrass stands as a result of nonrandom movement of cattle and subsequent grazing, trampling, and soil compaction (Fig. 1B).

\section{IMPLICATIONS}

Grazing disturbance and interference both appear to shape spatial patterns of crested wheatgrass stands in the northeastern Great Basin. Understanding how these important ecological processes operate through time provides new insight into how land users or managers can assess site conditions and develop strategies to trigger desirable vegetation changes. Our results suggest measurements of plant spatial patterns could augment rangeland-monitoring programs, which typically only measure plant cover or density. For example, assessment of plant spatial patterns may assist contemporary efforts to diversify crested wheatgrass communities (Cox and Anderson 2004; Pellant and Lysne 2005). In this context, identifying spatial patterns should better inform managers who need to better predict competitive interactions between plants when reducing crested wheatgrass dominance with mechanical and chemical methods. Thus, rapid recovery of crested wheatgrass from seed banks within 2-3 yr after reduction treatments (Hulet et al. 2010) and differential interference between crested wheatgrass and native species as seedlings (Gunnell et al. 2010) may depend not only on the specific management approach employed, but also on how grazing and interference affect site-specific plant spatial patterns.

Our observation of significant fine-scale regularity between individual plants in all plots confirms that interference interactions for water and nutrients are intense in crested wheatgrass stands. In the absence of grazing, interference intensity likely increases as regularity persists across broader scales in exclosure plots as compared to grazed plots. Our results also indicated that sustained disturbance by cattle in older stands creates significant aggregation, albeit at broader scales than regular patterns caused by interference.

\section{ACKNOWLEDGMENTS}

We thank E. Limbach and H. Bastian for helpful information related to site location, age, and disturbance history. We also thank J. Williams for providing site history data and assistance with site selection, and E. W. Schupp for insightful comments. Two anonymous reviewers also provided useful suggestions for improving the manuscript.

\section{LITERATURE CITED}

Adler, P. B., and S. A. Hall. 2005. The development of forage production and utilization gradients around livestock watering points. Landscape Ecology 20:319-333.

Adler, P. B., D. A. Raff, and W. K. Lauenroth. 2001. The effect of grazing on the spatial heterogeneity of vegetation. Oecologia 128:465-479.

Aguirre, L., and D. A. Johnson. 1991. Influence of temperature and cheatgrass competition on seedling development of two bunchgrasses. Journal of Range Management 44:347-354. 
AngelL, R. A. 1997. Crested wheatgrass and shrub response to continuous or rotational grazing. Journal of Range Management 50:160-164.

Armas, C., And F. I. PugnalRe. 2005. Plant interactions govern population dynamics in a semi-arid plant community. Journal of Ecology 93:978-989.

Asay, K. H., And D. A. Johnson. 1997. Genotype $\times$ competition level interactions in crested wheatgrass (Agropyron desertorum Poaceae: Triticeae). International Journal of Plant Sciences 158:851-855.

Asner, G. P., A. J. Elmore, L. P. Olander, R. E. Martin, and A. T. Harris. 2004. Grazing systems, ecosystem responses, and global change. Annual Review of Environment and Resources 29:261-299.

Baddeley, A., and R. Turner. 2005. Spatstat: an R package for analyzing spatial point patterns. Journal of Statistical Software 12:1-42.

Balph, D. F., and J. C. Malechek. 1985. Cattle trampling of crested wheatgrass under short-duration grazing. Journal of Range Management 38:226-227.

BESAG, J. 1977. Contribution to the discussion of Dr. Ripley's paper. Journal of the Royal Statistical Society B25:294.

Bisigato, A. J., M. B. Bertiller, J. O. Ares, and G. E. Pazos. 2005. Effect of grazing on plant patterns in arid ecosystems of Patagonian Monte. Ecography 28:561-572.

Blanco, P. D., C. M. Rostagno, H. F. del Valle, A. M. Beeskow, and T. Wiegand. 2008. Grazing impacts in vegetated dune fields: predictions from spatial pattern analysis. Rangeland Ecology \& Management 61:194-203.

Caldwell, M. M., and H. Richards. 1986. Ecophysiology of crested wheatgrass: a comparative study with bluebunch wheatgrass. In: K. L. Johnson [ED.]. Crested wheatgrass: its values, problems, and myths: symposium proceedings. Logan, UT, USA: Utah State University. p. 165-167.

Chatterton, H. J., and P. A. Harrison. 2003. Fructans in crested wheatgrass leaves. Journal of Plant Physiology 160:843-849.

Cox, R. D., AND V. J. Anderson. 2004. Increasing native diversity of cheatgrassdominated rangeland through assisted succession. Journal of Range Management 57:203-210.

Gunnell, K. L., T. A. Monaco, C. A. Call, and C. V. Ransom. 2010. Seedling interference and niche differentiation between crested wheatgrass and contrasting native Great Basin species. Rangeland Ecology \& Management 63:443-449.

HAASE, P. 1995. Spatial pattern analysis in ecology based on Ripley's K-function: introduction and methods of edge correction. Journal of Vegetation Science 6:575-582.

Henkin, Z., L. Hadar, and E. Noy-Meir. 2007. Human-scale structural heterogeneity induced by grazing in a Mediterranean woodland landscape. Landscape Ecology 22:577-587.

Hulet, A., B. A. Roundy, and B. Jessop. 2010. Crested wheatgrass control and native plant establishment in Utah. Rangeland Ecology \& Management 63:450-460.

HuLL, A. C., JR., AND G. J. KLomp. 1966. Longevity of crested wheatgrass in the sagebrush-grass type in southern Idaho. Journal of Range Management 19:5-11.

HuLl, A. C., JR., AND G. J. KLomp. 1967. Thickening and spread of crested wheatgrass stands on southern Idaho ranges. Journal of Range Management 20:222-227.

HuntLy, N. 1991. Herbivores and the dynamics of communities and ecosystems. Annual Review of Ecology and Systematics 22:477-503.

Keller, W., and A. T. BleAk. 1974. Growth and seed production of Nordan crested wheatgrass in a modified corn wheel. Crop Science 14:115-117.

KenKeL, N. C. 1988. Pattern of self-thinning in jack pine: testing the random mortality hypothesis. Ecology 69:1017-1024.

KINDSCHY, R. R. 1991. Alfalfa in crested wheatgrass seedings. Rangelands 13:244-246.

Law, R., J. Illian, D. F. R. P. Burglem, G. Gratzer, C. V. S. Gunatilleke, and I. A. U. N. GunatillekE. 2009. Ecological information from spatial patterns of the plants: insights from point process theory. Journal of Ecology 97:616-628.

LEPŠ, J. 1990. Can underlying mechanisms be deduced from observed patterns? In: F. Krahulec, et al. [EDS.]. Spatial processes in plant communities. Prague, Czech Republic: Academia. p. 178-196.

Maestre, F. R., J. Cortina, S. Bautista, J. Bellot, and R. Vallejo. 2003. Small-scale environmental heterogeneity and spatiotemporal dynamics of seedling establishment in a semiarid degraded ecosystem. Ecosystems 6:630-643.
Marlette, G. M., and J. E. Anderson. 1986. Seed banks and propagule dispersal in crested wheatgrass stands. Journal of Applied Ecology 23:161-175.

Mclntire, E. J. B., And A. Fajardo. 2009. Beyond description: the active and effective way to infer processes from spatial patterns. Ecology 90:46-56.

Mokeny, K., J. Ash, and S. RoxBuRgh. 2008. Effects of spatial aggregation on competition, complementarity, and resource use. Austral Ecology 33:261-270.

Monzeglio, U., and P. Stoll. 2005. Spatial patterns and species performance in experimental plant communities. Oecologia 145:619-628.

MurrelL, D. J. 2009. On the emergent spatial structure of size-structured populations: when does self-thinning lead to a reduction in clustering? Journal of Ecology 97:256-266.

Murrell, D. J., D. W. Purves, and R. Law. 2001. Uniting pattern and process in plant ecology. Trends in Ecology and Evolution 16:529-530.

OLSON, B. E., AND J. H. RICHARDS. 1989. Crested wheatgrass growth and replacement following fertilization, thinning, and neighbor plant removal. Journal of Range Management 42:93-97.

Pellant, M., and C. R. Lysne. 2005. Strategies to enhance plant structure and diversity in crested wheatgrass seedings. In: N. L. Shaw, M. Pellant, and S. B. Monsen [comps.]. [EDS.]. Sage-grouse Habitat Restoration Symposium Proceedings; 4-7 June 2001; Boise, ID, USA. Fort Collins, CO, USA: US Department of Agriculture, Forest Service, Rocky Mountain Research Station, RMRS-P-38. p. 81-92.

Phillips, D. L., and J. A. MacMahon. 1981. Competition and spacing patterns in desert shrubs. Journal of Ecology 69:97-115.

R Development Core Team [Computer program]. 2011. R: a language and environment for statistical computing. Version 2.10.0. Vienna, Austria: R Foundation for Statistical Computing.

Rayburn, A. P., K. J. Schiffers, and E. A. Schupp. 2011. Use of precise spatial data for describing spatial patterns and plant interactions in a diverse Great Basin shrub community. Plant Ecology 212:585-594.

RIPLEY, B. D. 1981. Spatial statistics. New York, NY, USA: Wiley. 252 p.

Rogler, G. A., And R. J. Lorenz. 1983. Crested wheatgrass-early history in the United States. Journal of Range Management 36:91-93.

SaliHI, D. O., AND B. E. NoRton. 1987. Survival of perennial grass seedlings under intensive grazing in semi-arid rangelands. Journal of Applied Ecology $24: 145-151$

Schenk, H. J., C. Holzapfel, J. G. Hamilton, and B. E. Mahall. 2003. Spatial ecology of a small desert shrub on adjacent geological substrates. Journal of Ecology 91:383-395

Selfan, M., And R. Kadmon. 2006. Indirect effects of cattle grazing on shrub spatial pattern in a Mediterranean scrub community. Basic and Applied Ecology 7:496-506.

Sharp, L. A. 1986. Crested wheatgrass: its values, problems and myths. In: K. L. Johnson [ED.]. Crested wheatgrass: its values, problems, and myths: symposium proceedings. Logan, UT, USA: Utah State University. p. 3-6.

Sharp, L. A., K. Sanders, and N. Rimbey. 1992. Variability of crested wheatgrass production over 35 years. Rangelands 14:153-168.

SkARPE, C. 1991. Spatial patterns and dynamics of woody vegetation in an arid savanna. Journal of Vegetation Science 2:565-572.

Stoll, P., and D. Prati. 2001. Intraspecific aggregation alters competitive interactions in experimental plant communities. Ecology 82:319-327.

Tirado, R., and F. I. Pugnaire. 2003. Shrub spatial aggregation and consequences for reproductive success. Oecologia 136:296-301.

[USDA nRCS] US Department of Agriculture Natural Resources Conservation Service. 2010. Ecological site information system. Available at: http://esis.sc.egov. usda.gov/. Accessed 3 August 2010.

Weintraub, F. 1953. Grasses introduced into the United States. Washington, DC, USA: US Department of Agriculture, Handbook 58. 79 p.

Wiegand, T., C. V. S. Gunatilleke, I. A. U. N. Gunatilleke, and A. Huth. 2007. How individual species structure diversity in tropical forests. Proceedings of the National Academy of Sciences of the United States of America 104:1902919033.

WiLlams, J. R. 2009. Vegetation characteristics of Wyoming big sagebrush communities historically seeded with crested wheatgrass in northeastern Great Basin, USA [thesis]. Logan, UT, USA: Utah State University. 99 p. 